provided an adequate complement; but their gallant efforts to assist in cases arising in other scientific fields only made it more manifest that the day of the comprehensive scientific expert witness had come to an end.

The Reports of Patent Cases bears witness to Ballantyne's amazing versatility. From his début in the famous Welsbach gas mantle litigation, he assumed the burden of scientific exposition in patent cases for more than thirty years, dealing with topics as diverse as gramophones, electric lamps and filaments, steel ball grinders, coal-cutting machines, typewriters, confectionery, the drying of milk and a host of others. The first encomium he received was in his first case and came from Mr. Justice Wills, who said in his judgment: "I wish to add that Mr. Ballantyne has given me reason to rely on him. $\mathrm{He}$ is one of the most truthful and fairest minded men I have seen in the witness box". "The last to my knowledge appears in an appreciation by Sir Kenneth Swan, a distinguished leader of the Patent Bar and himsolf a son of a great inventor. He wrote: "His evidence, invariably characterized by scrupulous candour and fairness, was not only backed by profound technical knowledge, but was always based on a careful and crucial experiment; moreover it was given with that degree of precision and tenacity that rendered it proof against the most penetrating crossexamination. In short, he was a pattern of what an expert witness should be". Both, it will be noted, remarked Ballantyne's candour and fair-mindedness, two attributes which the experienced judge will thankfully recognize, and without which the most profound scientific knowledge will fail to impress. The value of an expert witness resides in the weight attached to the expression of his opinions. He must, of course, be technically competent and preferably free from addiction to technical jargon. But in the ultimate result, his assistance in the administration of justice will depend not only upon his perception and expression of truth, but upon the manner in which he completes and isolates it. In this Ballantyne was pre-eminent, and that explains why it was that, in cases involving scientific questions with which he was only generally familiar, his assistance was often more valuable than the evidence of more specialized experts.

Horatio Ballantyne was born at Glasgow in $\mathbf{1 8 7 1}$. His father, Thomas Ballantyne, who was a pioneer of unitarianism in Glasgow, was married twice, and had thirteen children, Horatio being the eldest son and first child of the second marriage. His father died when Ballantyne was fifteon years old.

At fourteen he left school to begin work in the laboratory of Robert Tatlock, eity analyst for Glasgow. It had been planned that he should go to the University, having gained a bursary that would havo enabled him to do so, but the young Ballantyne resigned the bursary and went to Tatlock's, starting at a wage of $2 s$. per week.

It was a very busy commercial laboratory, with a large Students' Department attached, and gave a really extensive training in industrial chemical analysis. After some time Ballantyne became chief assistant, and Tatlock and his partner Thompson invited him to become, in 1898, a member of the firm when Dr. J. B. Readman was due to retire; but brighter prospects came his way.

During the years with Tatlock, he had opportunities for carrying on research, especially into the little.understood chemistry of the oils and fats. Some accounts of these investigations were published in the Journal of the Society of Chemical Industry. In the evenings he attended classes in chemistry, mineralogy, German, etc. He took first place in Great Britain in the 'South Kensington' examination in honours ehemistry, and the first place also (with medal) in the Society of Arts examination in German.

In March 1896 occurred an event which determined the course of his professional life. A few years before that date, Tatlock had received from Norway some samples of minerals which were to be tested for what was then known as the "rare earths", especially yttrium, cerium, lanthanum and thorium oxides. The invention of the incandescent gas mantle by Auer von Welsbach had given a special value to such earths, the chemistry of which was quite unknown to chemists in general. Tatlock had passed on to Ballantyne the problem of working out methods of analysis, etc., and he became in a small way a specialist in this recondite subject.

The Welsbach Incandescent Gas Light Co. of London acquired the rights to the British Welsbach patents, and by the year 1895 had become so successful that many infringing manufacturers appeared. An action for infringement of patent was brought against one of them. Towards the end of October 1895 a specimen of the infringing article was sent to Tatlock for analysis, and as it was said to be made of the rare earths he handed over the problem to Ballantyne. In March 1896 Ballantyne was asked unexpectedly to proceed immodiately to London to be present at the trial of the action. The case began before $\mathrm{Mr}$. Justice Wills. Fortunately for Ballantyne, it turned out to be the most important case of the time. The principal leaders of the Patent Bar were engaged in it, as were the leading expert witnesses (Sir Henry Roscoe, Prof. (Sir) James Dewar, Dr. Otto Hehner, (Sir) James Swinburne, Dr. Dupre, (Sir) Dugald Clerk, John Murrey, Prof. Vivian B. Lewes, Prof. Lambert, etc.). Leading counsel for the patentee was $J$. Fletcher Moulton (afterwards Lord Moulton), at that time the most distinguished counsel at the Patent Bar. The trial of the action was very protracted. Most of the work on the controversial matters fell upon Ballantyne's shoulders and he worked feverishly, night and day. Three times he was called to the witness-box. Such was the event which began Ballantyne's career as an expert witness and led him to specialize in patents and cognate matters.

Ballantyne was elected vice-president of the Institute of Chemistry in 1918, and again for the years 1920-22. He served on a number of Board of Trade departmental committees dealing with patent, law and practice and with inventions made in government service. He married in 1899 Miss $\mathrm{K}$. Russell, who survives him with the three daughters of the marriage.

G. H. LLOYD-JACOB

\section{Mr. D. B. Waters}

David Bowe Waters, whose death occurred on February 7 at Glasgow at the age of forty-three, was a civil engineer and was responsible during the Second World War for much of the detailed technical develop. ment at the Road Research Laboratory (Department of Scientific and Industrial Research) of the devices known as 'plastic armour' and 'plastic protective plating' : these materials were used on most of the Allied merchant ships for the protection of vital parts 
from aireraft cannon fire. 'Plastic armour' consisted of a tightly packed mass of stone particles held together by a bituminous mortar and backed by a steel plate; 'plastic protective plating' was an even denser material with a higher stone content compacted by vibration and encased in thin sheet steel. In essence, these devices provided a protective layer, the resistance of which to penetration was highly irregular, thus causing projectiles to yaw away from a straight path.

Mr. Waters joined the Bituminous Section of the Road Research Laboratory in 1936 : at the time of his death he was in charge of the Laboratory's Scottish branch at East Kilbride. His colleagues will long remember his originality of mind, enlivened always by gaiety and wit.

\section{Dr. Ernst Wanner}

Dr. Frnst Wanner was born in Zurich on July 22, 1900. In 1925, he was awarded the degree of doctor of mathematics at Zurich for work on groups of linear transformations, and in 1928 was appointed to the Swiss Meteorological Service, where he remained until his death from a heart attack on November 4, 1955.
He worked on magnetic variations at Regensberg and on seismology at Zurich. Latterly he was vice. director of the Swiss Meteorological Service and responsible for personnel. That he was successful in both these fields is a tribute to him both as a scientist and as a man. He was basically good-natured, modest and very straightforward.

With A. Kreis, Wanner constructed a 1,000-kgm. vertical seismograph, which assisted him in obtaining data for the study of Swiss earthquakes and their impact on Alpine structure. He also studied Swiss earthquakes historically, compiling a catalogue of shocks between the dates 1856 and 1879. With all this material he was able to work out the correlation between earthquake epicentres in Switzerland and Swiss Tertiary volcanies and thermal springs. $\mathrm{He}$ used a method due to G. Polya and F. Eggenberger on the coupling of earthquake aftershocks. Finally, with P. L. Mercanton, Wanner studied the magnetic anomaly in Jorat, near Lausanne.

Wanner was president of the Swiss Committee of the International Union of Geodesy and Geophysics, vice-president of the International Association of Seismology and the Physics of the Earth's Interior, and the Swiss representative on the European Seismological Commission. He was unmarried.

ERNEST TIILOTSON

\section{NEW FELLOWS OF THE ROYAL SOCIETY}

$\mathrm{A}^{\mathrm{T}}$ The meeting of the Royal Society on March 15, the following were elected to fellowship :

Dr. N. P. Allew, superintendent, Metallurgy Division, National Physical Laboratory, Teddington, Middlesex, distinguished for his work on alloy steels, their transformations, and their engineering properties

Prof. J. F. BAKER, professor of mechanical sciences, University of Cambridge, distinguished both for his experimental and theoretical investigations of steel structures and for services to education in engineering.

Prof. R. M. Barrer, professor of chemistry, Tmperial College of Science and Technology, London, distinguished for his work on the mechanism of adsorption and diffusion of gases in solids and the problem of molecular sieves in zeolite minerals.

Dr. R. Brown, head of the Agricultural Research Council Unit of Plant Cell Physiology, Oxford, distinguished for his work on germination of parasitic seeds and isolation of germination hormones, also for studies of factors involved in cell division and development.

Prof. J. A. V. ButLer, professor of physical chemistry, University of London, distinguished for his work on thermodynamies, and the application of physical techniques for the solution of problems of molecular structure of deoxyribonucleic a.cids.

DR. D. GABOR, Mullard reader in electronics, Imperial College of Science and Technology, London, distinguished for his work on transient electric phenomena, electron microscopy, the theory of communication and the electric arc plasma.

DR. H. GRÜNEBERG, reader in genetics, University of London, distinguished for his investigations into the expression of genes during development in mammals.
DR. C. S. HALIPIKE, director, Otological Research Unit of the Medical Research Council, London, distinguished for his investigations of the physiology and pathology of the internal ear and the mechanisms of hearing and equilibration.

Prof. J. E. Harris, professor of zoology, University of Bristol, distinguished for his researches in several branches of experimental zoology.

W. K. HaYman, reader in analysis, University of Exeter, distinguished for his contributions to the theory of functions of a complex variable.

Prof. N. Kemmer, Tait professor of natural philosophy, University of Edinburgh, distinguished for his pioneering work on the fundamental particles of physics, particularly on the meson and its role in determining forces within the atomic nucleus.

DR. N. KURTI, lecturer and demonstrator in physics, University of Oxford, and Senior Research Fellow, Brasenose College, distinguished for his work on phenomena at very low temperatures, particularly in paramagnetism and nuclear alignment.

Dr. R. G. MacFarlane, Radcliffe lecturer in hæmatology, University of Oxford, distinguished for his studies on blood coagulation and their application for the treatment of hæmophilia.

DR. R. Markham, principal scientific officer, Plant Virus Research Unit (Agricultural Research Council), Cambridge, distinguished for his studies on plant viruses and for his contributions to knowledge of nucleic acids.

Dr. J. W. MITCheLL, reader in physics, University of Bristol, distinguished for his work on the action of light on crystals, particularly in photographic emulsions, and on the nature of the photographic latent image. 